\title{
STUDY THE EFFECT OF SALINITY AND NUTRIENTS FOR THE GROWTH OF Najas marina AND ITS IMPACT TO AQUATIC BIODIVERSITY IN MADU GANGA RAMSAR WETLAND IN SRI LANKA
}

\author{
A.A.D. Amarathunga ${ }^{*}$ N. Sureshkumar, K. A.W.S. Weerasekara, W.D.N. \\ Wickramaarachchi and S. A. M. Azmy
}

\author{
Environmental Studies Division, National Aquatic Resources Research and Development Agency \\ (NARA), Sri Lanka \\ E mail -Deeptha.amarathunga@gmail.com. Telephone: +94-11-2521006; Fax: + 94-11-2521009
}

\begin{abstract}
Madu Ganga is the latest addition to the Ramsar International Convention of Wetlands. Najas marina is an alien aquatic plant and $0.5 \mathrm{~m}$ long that are often branched toward the upward portion of the plant. The objective of the study was to study the impact of salinity and nutrients for the growth of Najas marina. Samples were collected for analysed water quality parameters from March, 2006 to January 2007 in the lagoon. Mapping was done using Garmin GPS map 76CS and Arc GIS used to developed maps.

Mean nutrient such as, nitrate nitrogen, ammonia nitrogen and orthophosphate concentrations were observed $0.26 \pm 0.3 \mathrm{mg} / \mathrm{l}, 0.057 \pm 0.04 \mathrm{mg} / \mathrm{l}$, and $0.354 \pm 0.77 \mathrm{mg} / \mathrm{l}$ subsequently. Mean salinity variation in bottom and surface are $6.38 \pm 6.65 \mathrm{ppt}$ and $4.31 \pm 4.68 \mathrm{ppt}$. Higher bottom salinity was observed in location number 02 (near to sea mouth) and Najas marinawas not present in the area. Najas marina was also not recorded in upper part of the lagoon and fresh water streams studied. High density of Najas marina plants were observed in sampling location 07, 08 and 09, because of the high nutrient concentration flowing through feeding tributaries. More than $25 \%$ of lagoon area was covered by Najas marina.
\end{abstract}

Key Words: Najas marina, Maduganga, Salinity and nutrients

\section{INTRODUCTION}

Sri Lanka's highland massif, located in the south central part of the island is the most important geographic determinant of inland water resources. The radial drainage pattern that carries surface water down from the high watersheds includes 103 rivers basins that cover 90 percent of the island (Arunugum, 1969). Madu Ganga is popularly called a river and it has 59 sq. km catchment area and most unique biodiversity including different vegetation types such as the predominating mangroves and marshlands. Maduganga is the latest addition to the Ramsar International Convention of Wetlands and it's consists of 10 major wetland vegetation types.

Madu Ganga has several vegetation types and rich biodiversity. These vegetation types harboured a total of 303 species of plants belonging to 95 families. The total plant species included 19 endemics, 8 nationally threatened species and 9 invasive alien species. A total of 248 species ofvertebrate fauna, belonging to 121 families were recorded from Madu Ganga. These included 20 species $(8 \%)$ of endemics, while 30 species $(12 \%)$ are nationally threatened. The native vertebrate fauna of Madu Ganga represents 30\% of Sri Lanka's native inland vertebrate species (IUCN, 2001). Cinnamon cultivations form the dominant land use type in the area. At present, a nature based tourism industry is developing rapidly at Madu Ganga. In addition, resident traditional fishermen are involved in commercial fishing activities in the Madu Ganga estuary (CEA/Euroconsult, 1997). 
Invasive aquatic species are one of the four greatest threats to the world's oceans, lagoons, freshwater bodies and can cause extremely severe environmental, economic and public health impacts. Najas marina or 'katu penda' is one of the nine invasive species that have been identified in the Madu Ganga wetland system in Sri Lanka (Bamberadeniya, et al 2002). Najas marina is up to about $0.5 \mathrm{~m}$ long that are often branched toward the upward portion of the plant. The internodes of the stem usually have conspicuous, brownish, prickly teeth. The leaves are opposite or sometimes in whorls of three, 0.5 to $4.0 \mathrm{~cm}$ long, and have triangular teeth along the leaf margins and prickles along the midrib on the underside of the leaf. Plants are dioecious with the male and female flowers borne on separate individuals. The flowers are solitary in the leaf axils.

The female flowers produce ovoid seeds 2.0 to $4.5 \mathrm{~mm}$ long that have 3 to 4 -angled areolae that are irregularly arranged. The Special Area Management plan identifies environmental issues in the lagoon as decrease of fish in the lagoon due to closure of lagoon mouth, destructive fishing methods, lack of quantitative data on fish and aquatic weeds (especially Najas marina). Therefore, the research aim was to identify the effect of salinity and nutrients for the growth of Najas marina and its impact to aquatic biodiversity in Madu Ganga ramsar wetland

\section{METHODOLOGY}

Seven months samples were collected for water quality from March, 2006 to January 2007 in the lagoon. Najas marina was investigated during the study period.The numbers of predetermined 10 sampling locations were selected using random sampling technique, along the Madu Ganga lagoon. The locations of sampling stations are given in fig. 01. At each sampling station water was sampled at the surface in 0.5 to 1.0 meter height while the depth exceeded 1.5 meter, bottom water sample was also collected. Samples were collected using Ruttner sampler (APHA 1998).

Collected samples were analysed accordance with Standard Methods for Examination of Water and Waste Water (APHA) 20th edition for various water quality parameters such as ammonia, phosphate, nitrate and nitrite. In-situ analysis were conducted for the determination of $\mathrm{pH}$, measured by $\mathrm{pH}$ meter (Orion 260A), dissolved oxygen level was measured using portable meter (Orion 830A), turbidity level was measured using portable turbidity meter (Hach 2100P), and salinity measured using portable meter (HATCH- SensIon 5), Samples were then fixed for the determination of the rest of the selected parameters. The laboratory analyses were carried out immediately for the purpose of avoiding any changes in the chemical quality.

Two field visits were done with the objective of mapping Najas marina in Madu Ganga lagoon and Garmin GPS map 76CS and Arc GIS software were used to developed maps. Other information was collected through Participatory Community Appraisal from relevant stakeholders. Data analysis was done using Minitab and Microsoft Excels software packages. 


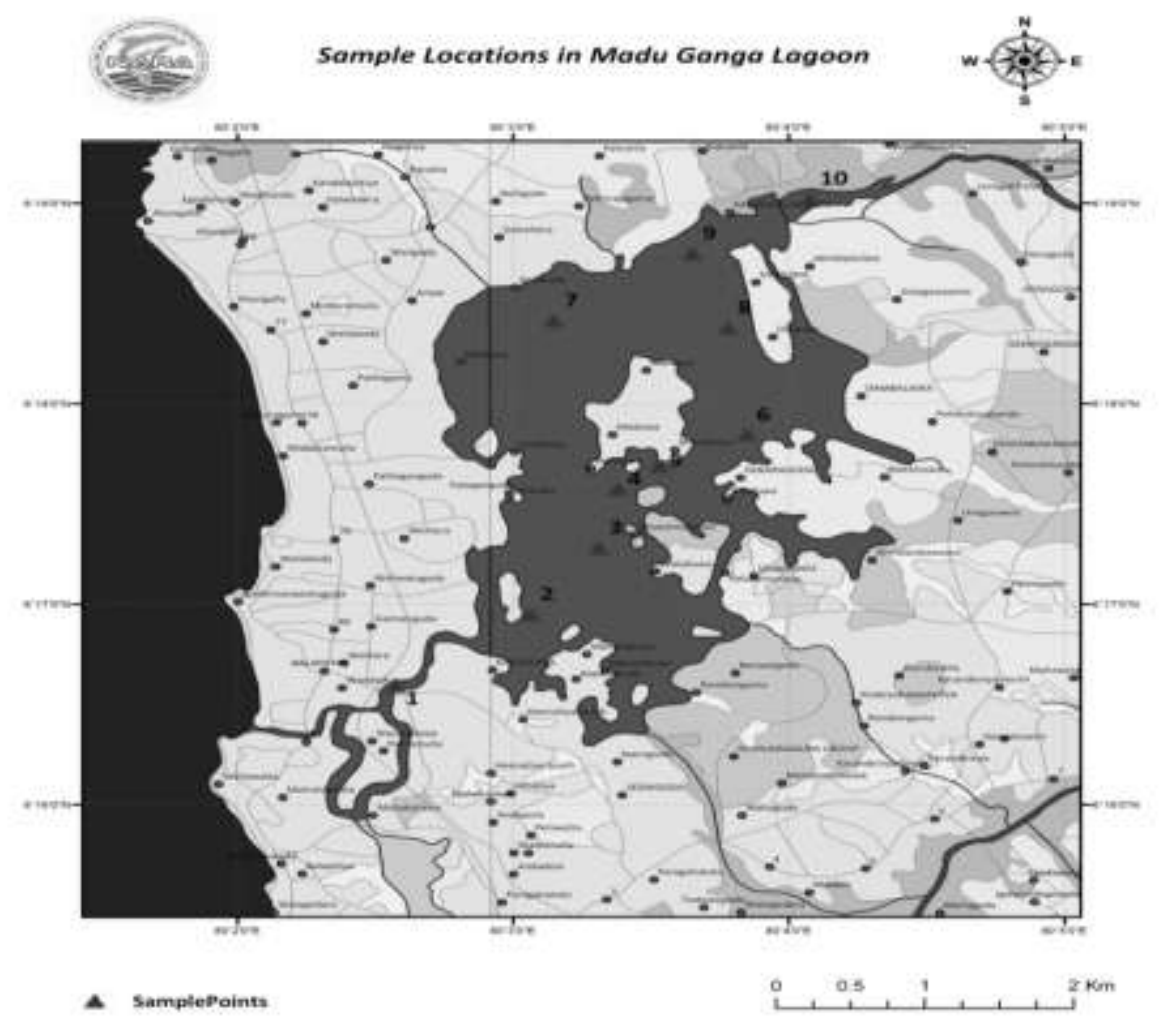

Figure 01: Sampling locations of Madu Ganga lagoon

\section{RESULTS AND DISCUSSION}

\subsection{NUTRIENT AVAILABILITY IN THE LAGOON}

Coastal ecosystems received considerable amount of materials including contaminants, from land and exchange with the open ocean (Howarth et al., 1996). Associated with freshwater discharge, significant amounts of nutrient were drain in to Madu Ganga lagoon (Amarathunga \& Sureshkumar, 2009). Ammonium concentrations varied from $0.01 \mathrm{mg} / 1$ to 0.21 with the higher values occurring during dry period events and heterotrophic activity is at its maximum. Figure 02 shows nitrate nitrogen and phosphate variation in the lagoon. Nitrate concentration was varies between $0.006 \mathrm{mg} / \mathrm{l}$ to $1.68 \mathrm{mg} / \mathrm{l}$ and recorded on January and April months, respectively. Mean nitrate nitrogen concentration was observed $0.26 \pm 0.3 \mathrm{mg} / \mathrm{l}$. As well as, Nitrite nitrogen concentration was observed between $0.0004 \mathrm{mg} / \mathrm{l}$ to $0.0063 \mathrm{mg} / \mathrm{l}$ and mean nitrite nitrogen concentration was observed $0.002 \pm 0.001 \mathrm{mg} / \mathrm{l}$. Nutrient sources are hundreds of kilometres upstream from impacted water bodies and only a small proportion of the total sediment and nutrient load moving within a catchment is delivered downstream.

Fine suspended sediment carries with it nutrients that are ultimately available to algal growth. When consider the aquatic plant growth, dissolve phosphate play a major role. Recorded dissolve phosphate concentration in lagoon was ranged from $0.006 \mathrm{mg} / \mathrm{l}$ to 2.92 $\mathrm{mg} / \mathrm{l}$. High dissolve phosphate concentration was observed in month of April and higher phosphate concentrations were occurredduring April to July months. The low phosphate variation suggests that phosphate is tightly cycled within the system (Molinero and Burke 2003). Nutrient impaired waters can cause problems that range from annoyances to serious health concerns (Dodds and Welch 2000). 


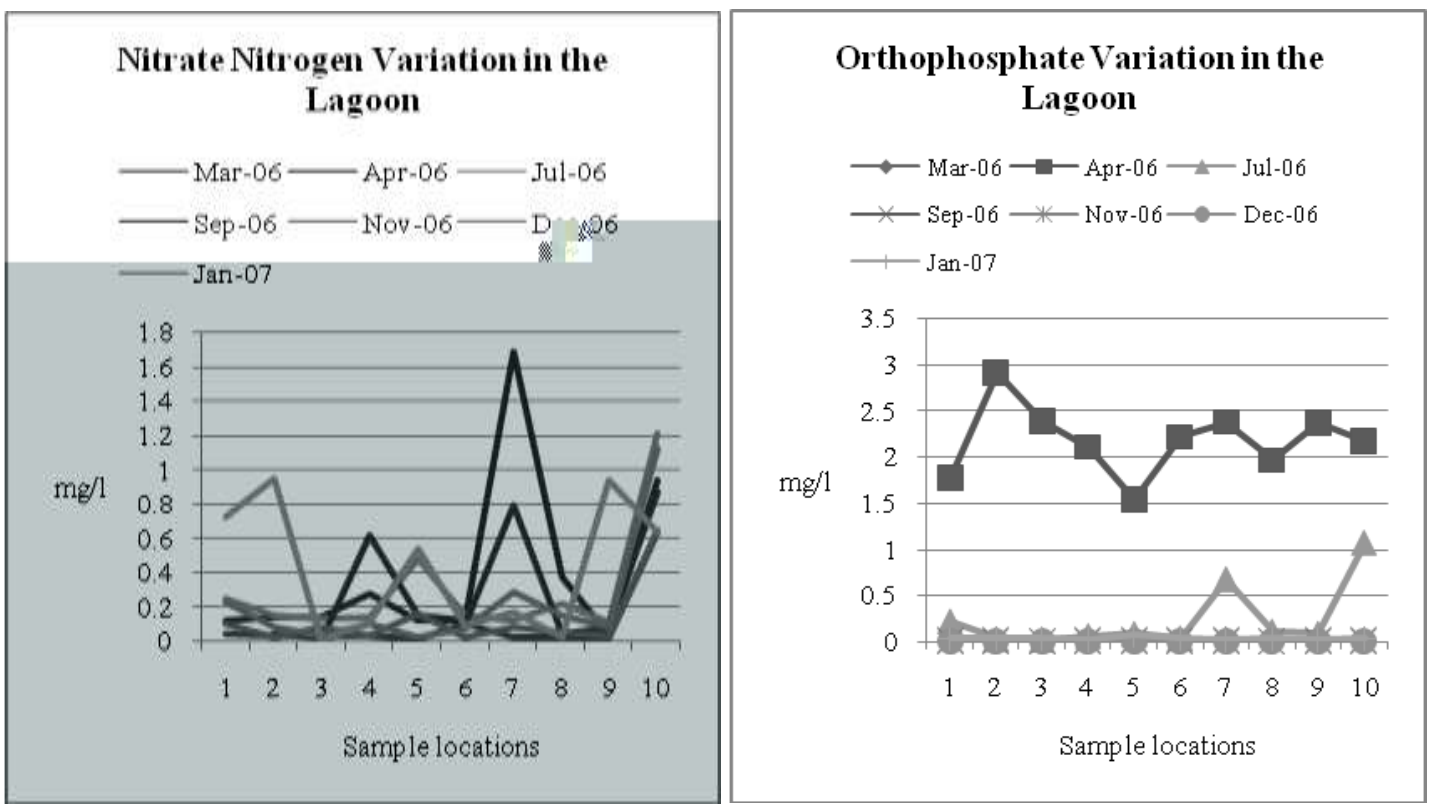

Figure 02: Variation of nitrate nitrogen and orthophosphate concentration in the lagoon

Nuisance levels of algae and other aquatic vegetation (macrophytes) can develop rapidly in response to nutrient enrichment when other factors (i.e., light, temperature, substrate, etc.) are not limiting. High macrophyte growth can interfere with aesthetic and recreational uses of stream systems (Welch et al, 1992). High nutrient loads bring by main feeding streams to lagoon. These nutrients were deposit in the lagoon bottom and recycle by aquatic plants mainly Najas marina. High density of Najas marina plantswere observed in sampling location 07,08 and 09 , because of the high nutrient concentration flowing through feeding tributaries.

\subsection{VISIBILITY AND LIGHT PENETRATION TO LAGOON BOTTOM}

The replacement of land cover with impervious surfaces during development can have significant effect on water shade hydrology and riparian function. One such concern is a decrease in water quality, which is generally reflected by increase of particulate matter in water body (Mullisset al., 1996; Webb and Walling, 1992). The composition and concentration of particulate matter in the aquatic environment is effected by the source and pathway of sediment input (Eisma, 1993; Webster et al., 1990).Results reveal that, mean turbidity value was $7.44 \pm 3.8 \mathrm{NTU}$ and a recorded turbidity value varies between $2.56 \mathrm{NTU}$ to 23.0 NTU. Therefore, light penetration to bottom is very low. Turbidity is used to measure the visibility in water. Turbidity measures of particulate matter suspended in the water column, however turbidity is dependent on the particle size and their ability to scatter light (Gippel, 1995). When consider the total suspended solids (TSS) in lagoon varied between $1.33 \mathrm{mg} / \mathrm{l}$ to $72.5 \mathrm{mg} / \mathrm{l}$ and mean value is $12.97 \pm 9.8 \mathrm{mg} / \mathrm{l}$. As well as, mean chlorophyll-a concentration is $11.38 \pm 8.9 \mathrm{mg} / \mathrm{m}^{3}$. The results reveal that, the light penetration in the lagoon is very poor. Therefore, decomposition rate in the bottom is very low.

\subsection{VARIATION OF SALINITY AND ITS IMPACT TO Najas marina}

There are many estuaries which do not always have a balance between salinity-ingress and egress. Often such an imbalance arises due to time dependence in the freshwater runoff into the estuary (Banas et al, 2004). There are many streams join to the estuary with major stream called as Lenagala Ela. 


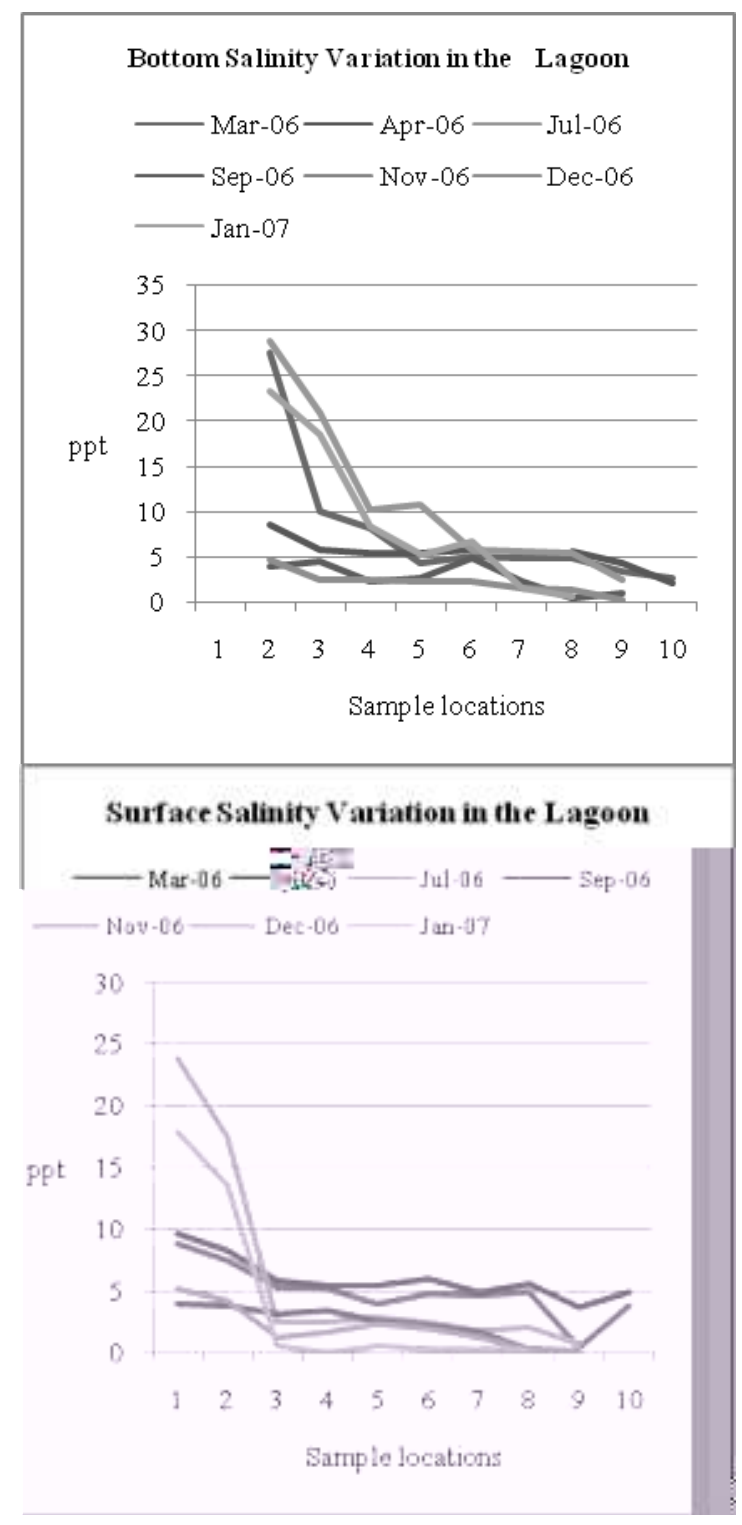

Figure 03: Bottom and surface salinity variation from sea mouth to upstream along the lagoon

These streams bring freshwater to the estuary during the rainy season. This monsoonal precipitation has spikes of high rainfall during active spell of the monsoon and the runoff is high following an episode of the precipitation over the catchment area of streams that feed the estuary. Therefore, the salinity in the estuary in upstream was not observed. As runoff decrease, during the dry season the salinity in the estuary is increase. Fig 03.shows the bottom salinity in the estuary changes during a year. The salinity was recorded from sea mouth to upstream along the estuary. 28.88ppthighest bottom salinity was recorded in month of July at a distance of 500-1000 m from the sea mouth of the lagoon. Fig. 03 shows the surface salinity variation along the lagoon and surface salinity concentration was decreased along the lagoon. 23.88 pptmaximum surfacesalinity concentration was recorded at near to sea-mouth on month of July. Both graphs show dramatic decrease of salinity from sea mouth to lenagalaela.

\subsection{SPREADING OF Najas marina AND ITS IMPACT TO BIODIVERSITY}

Madu Ganga lagoon is rich in biodiversity, it has a total of 98 plant species, total of 248 species of vertebrate fauna, belonging to 121 families were recorded from Madu Ganga. 
These included 20 species $(8 \%)$ of endemics, while 30 species $(12 \%)$ are nationally threatened. The native vertebrate fauna of Maduganga represents 30\% of Sri Lanka's native inland vertebrate species (Bamberadeniya, et al 2002).

Many of the introduced species are sun-loving plants and require a nutrient rich soil for their establishment and expansion (Teo et al., 2003). Pollution, sedimentation, eutrophication, degradation of the ecosystem and excessive growth of aquatic weeds can be considered as the main threats to aquatic ecosystems. Excessive growth of aquatic weeds often effect reduces water quality, decline fish production, alter the biodiversity, increase human etc., (Amarasinghe, 2008). Water plants (hydrophytes) occur at sites that are permanently or almost permanently submerged. Such plants are adapted to living in water: they often lack supporting tissues, have floating leaves and often take up nutrients directly from the surrounding water rather than from the soil via roots, According to findings, Madu Ganga was showed high nutrient concentration.

Generally, nitrate which is considered as the most important plant nutrient (Russell 1978; Nagarajah et al., 1988). Therefore, high growth rate of Najas marina plants in Madu Ganga was very high. Also, dissolve phosphate in lagoon is very high and it is consider as most important to plant growth (Enger and Smith, 1991). In most causes phosphorus accelerates the eutrophication due to growth of flora in waters. Therefore, controlling aquatic plants mainly requires reducing phosphorus inputs to surface waters. Introduced plant can have similarly disastrous long-term effects on local biological diversity and local economy. All of these species are adaptable, growing rapidly and in the absence of natural predators are capable of spreading quickly, results lowered oxygen level in water, impede fisheries and drainage etc, (www.wetlands.org).As mentioned earlier, 9 invasive alien plant species were also documented from Maduganga.

The terrestrial invaders include Annonaglabra, Swieteniamacrophylla, Alstoniamacrophylla, Chromolaenaodorata, and Lantana camara, while the aquatic invaders include Eichhorniacrassipes, Salviniamolesta, Hydrillaverticillata and Najas marina. Of these invasive plants, Annonaglabra, Hydrillaverticillata and Najas marina have spread into many places in Maduganga (Bamberadeniya, et al 2002). According to PCA, the two submerged invaders - Hydrillaverticillata and Najas marina have entered Maduganga about 10 -12 years ago. The dense mats of Najas marina plants leads to drastic fluctuations of dissolved oxygen, When consider the dissolve oxygen in the lagoon was varies between $1.5 \mathrm{mg} / \mathrm{l}$ to $10.07 \mathrm{mg} / \mathrm{l}$ and lowest dissolve oxygen concentration was recorded in sample location 2, 5 and 7 . Thus, the lower concentration of dissolve oxygen in water is affecting the aquatic fauna. Many fish kill incidents were recorded in Madu Ganga lagoon recent past.

Invasive species, introduced either deliberately or inadvertently to one part of the world and which become competitors, predators or parasites of indigenous species, are responsible for declines in many native species populations. This aquatic plant is found in submerged with shallow, slightly brackish, open water within $1-2.5 \mathrm{~m}$ depth. Starting point of mapping is sea mouth and not observes Najas marina species in that area. Normally, sea mouth opens in seasonally and due to that reason high salinity around the sea mouth. This will lead to reduction of growth of Najas marina in the area. Also not observe Najas marina when, going through in narrow stretch to lagoon and salinity of this area also high. This is due to that reason leads to reduction of growth of Najas marina in the area. Najas marina is critical to a well-structured fish assemblage to Madu Ganga. They not only provide protection for small fish from predators but also produce large numbers of invertebrates for small fish. As well as, Najas marina plants also are an important food source for many species of waterfowl in the form of vegetation-dwelling invertebrates or the plants themselves. 


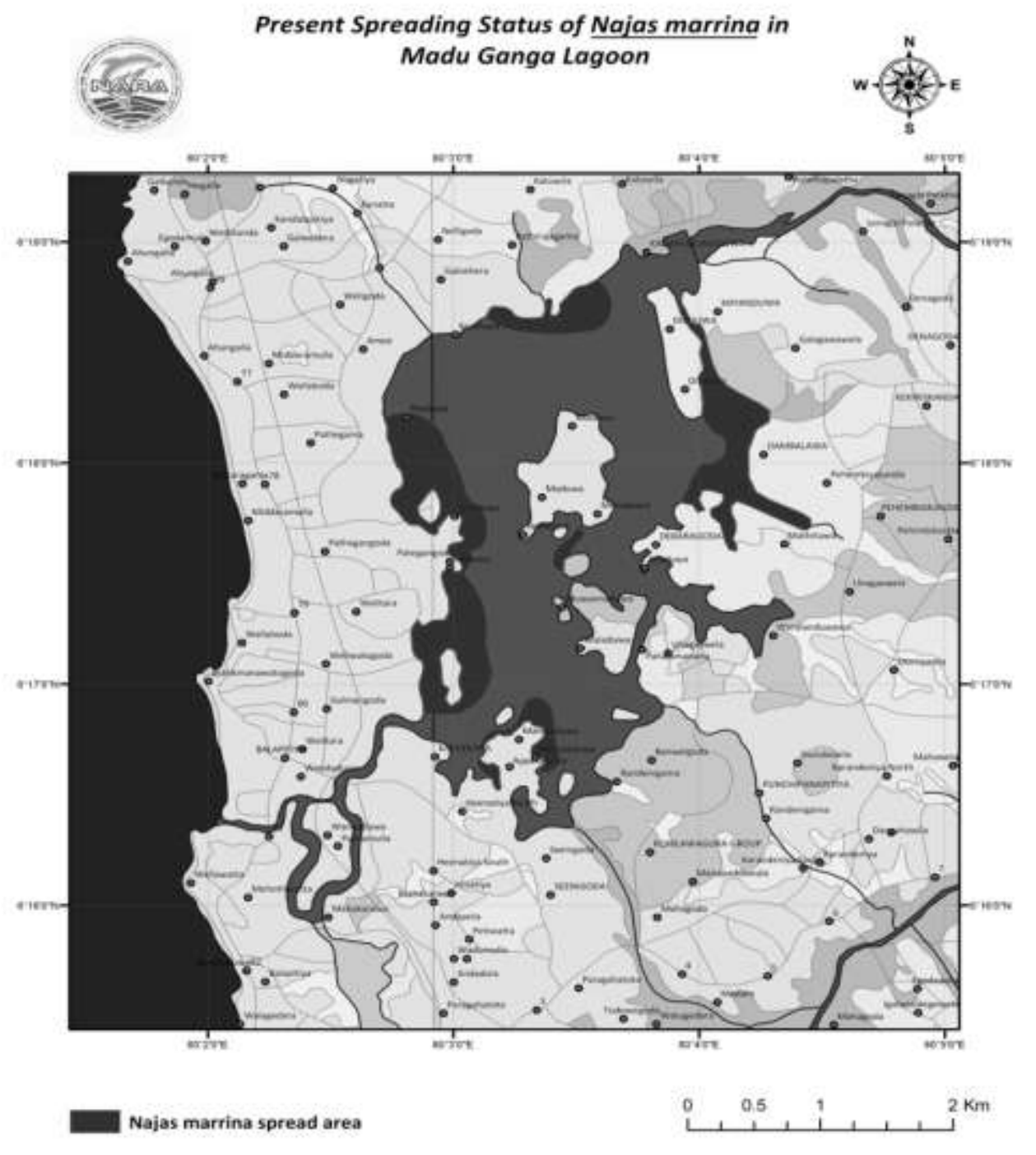

Figure 04: Spreading of Najas marina in Madu Ganga lagoon

This is especially important on islands and in freshwater ecosystems, where they are thought to be the main threat to endemic species.Therefore, certain management procedures will need to avoid further spreading of Najas marina towards the interior of the lagoon However, have an effect on water quality and they put oxygen into the water is an obvious contribution, but they also provide for long-term storage of nutrients that might otherwise be used to create nuisance levels of planktonic or filamentous algae, however, after decomposing of plants, nutrients will help to new Najas marina plants growth vigorously. Therefore, spreading is very fast in the lagoon. The result is Najas marina dominates in the lagoon and other native aquatic plants shifted.

\section{CONCLUSION}

Results revealed that, nearly $25 \%$ of the lagoon was covered by Najas marinaand spreading is thriving by high loading of nutrients from the catchments. It reduces biodiversity in the lagoon and prompt actions should be taken to control the spreading of Najas marina. Therefore, certain management practices should be implemented after accomplishing further research on Najas marina. 


\section{ACKNOWLEDGEMENTS}

The authors wish to acknowledge the competent technical assistance provided by the staff of Environmental Studies Division of NARA.

\section{REFERENCES}

Amarathunga A. A. D. and N. Sureshkumar, 2009.Comparison of Physico-Chemical Characteristic of the Feeding Tributaries and Nutrient Load bringing to Madu Ganga Lagoon. Sri Lanka Association for Advancement of Science, Proceedings of the 65th Annual Session, Sri Lanka. 426/D, 91pp

APHA, 1998, Greenburg A.E., Rhodes T.R., and Lenore S.C. Standard Methods for the Examination of Water and Waste water, 20th edition, APHA/AWWA/WEF

Arumugam.S. 1969.Water Resources of Ceylon.Water resources Board Colombo.

Bambaradeniya, C. N. B., S. P. Ekanayake, L. D. C. B. Kekulandala,R. H. S. S. Fernando, V. A. P. Samarawickrama, \& T. G. M.Priyadharshana. 2002. An Assessment of the Status of Biodiversityin the Maduganga Mangrove Estuary. Occ. Pap. IUCN, Sri Lanka.,

Banas, N.S., Hickey, B. M., MacCready, P. 2004.Dyanamics of Willapa bay, Washington: a highly unsteady, partially mixed estuary. Journal of physical Oceanography 34, 2413-2427P

CEA/Euroconsult 1997.Madu Ganga Estuary - Wetland Site Report \& ConservationManagement Plan, Central Environmental Authority.

Dodds, W. K. and E. B. Welch. 2000. Establishing nutrient criteria in streams. J. N. Am. Benthol. Soc. 19:186-196.

Enger, E.D. and Smith, B.F. 1991. Environmental Science: A study of interrelationships, fourth edition, Wm. C. Brown publishers, USA. 80-82pp.

Eisma, D. 1993. Suspended Matter in the Aquatic Environment. Springer-Verlag, Berlin, Germany.

Gippel, C.J., 1995. Potential of turbidity monitoring for measure the transport of suspended solids in streams, Hydrological process, Vol. 09.N0.01. 83-97 pp.

Howarth, R.W., Schneider, W.R., Swaney, D. 1996. Metabolisum and organic carbon fluxes in the tidal freshwater Hudson River, Estuaries 19, 848-865.

Molinero, J., and R.A. Burke. 2003. Nutrient concentrations and land use in small streams of the Georgia Piedmont. In K.J. Hatcher, ed., Proceedings of the 2003 Georgia Water Resources Conference, pp. 821-824.University of Georgia Publisher, Athens, GA.

Mulliss, R.M., Revitt, M., Shutes, R.B. 1996.The Impacts of Urban Discharges on the Hydrology and Water Quality of an Urban Watercourse.The Science of the Total Environment.189/190: 385-390.

Nagarajh, S., B. N. Emersion., V. Abeykoon and S. Yogalingam.1988. Water quality of some wells in Jaffna and Kilinochchi with special reference to nitrate pollution. Tropical Agriculturist 144: 61-78 pp Russell, E. W. (1978). Summary of technical discussion. In: Effect of intensive fertilizer use on the human environment. Soil Bulltin No.16, 1-14pp, FAO, Rome.

Teo, D.H.L., H.T.W. Tan, R.T. Corlett, M.W. Choong and S.K.Y. Lum. 2003. Continental rain forest fragments in Singapore resist invasion by exotic plants. J. Biogeography 30:305-310. 
Webb, B.W. and Walling, D.E. 1992. Water Quality II: Chemical Characteristics. In: Rivers Handbook: Hydrological Ecological Principles (eds: Calow, P. and Petts, G.E.). Blackwell Scientific, Oxford, UK.

Webster, J.R., Golladay, S.W., Benfield, E.F., D'Angelo, D.J. and Peters, G.T. 1990. Effects of Forest Disturbance on Particulate Organic Matter Budgets of Small Streams.Journal of the North American Benthological Society. 9(2): 120-140.

Welch, E. B., J. M. Quinn, and C. W. Hickey. 1992. Periphyton biomass related to pointsourceenrichment in seven New Zealand streams. Water Res. 26:669-675. Wetlands[online]. Available from:http://www.wetlands.org/RSIS/_COP9Directory/Directory/2LK003.html[Accessed 15 September 2010]. 